clinical syndromes to guide genetic counselling. McKusick's major purpose, however, was to create a list of traits that could subsequently be mapped. In this book, the term 'mapping' has several meanings and is often used synonymously with 'sequencing.' The correct definition of mapping is either to place genes into a linear order (genetic mapping) or to assign them to chromosomal regions (physical mapping). The contribution of OMIM to gene mapping and the subsequent completion of the human genome sequence is immense.

In 'Jewish Genes', Lindee tells the story of familial dysautonomia, a rare recessive disorder characterized by lack of tears, autonomic dysfunction and emotional lability. Starting with the delineation of the phenotype and the development of a diagnostic skin test, she then discusses the mapping of the location of the disease gene and prenatal molecular testing by linkage analysis in affected families, and finally the identification of the mutant gene and its function. She allows the reader to enter the body of an affected individual and imagine living with the disease. It has highly variable clinical manifestations, induding episodes of fever and high blood pressure, impaired taste, vomiting, insensitivity to pain, undue reaction to anxiety and lack of motor coordination. The story of familial dysautonomia also focuses on the interactions between foundations that distribute research money, collected from affected families and their friends, and researchers who accept the funds and commit to work on the disease. The spectrum of interactions ranges from mutual support and respect to competitiveness and secretive behaviour.

These fascinating, well-written stories portray what it is like to work in human or medical genetics, both in the clinic and as a researcher. Nowadays, medical genetics is an established medical speciality, unlike 'genomic medicine, which is a poorly defined futuristic term. Students and researchers in genetics and other fields of biomedicine are likely to gain new perspectives on their own work by reading this book. And because everybody is a healthcare consumer, general readers may well identify with certain actors in these stories. Uta Francke is in the Department of Genetics, Stanford University School of Medicine, Stanford, California 94305-5323, USA.

\title{
In the minds of animals
}

Animal Passions and Beastly Virtues:

Reflections on Redecorating Nature

by Marc Bekoff

Temple University Press: 2005.320 pp.

$\$ 70.50$ (hbk), $\$ 26.95$ (pbk)

\section{Scott Creel}

In T. H. White's The Once and Future King (G. P. Putnam, 1958), Merlin educates a young King Arthur by transmogrifying him into other creatures. Sometimes Arthur is an ant, and considers everything in the world only as 'done' or 'not done'. Sometimes he is a falcon, overcome in mid-sentence by a desire to kill his conversational partner. For many of us, the game of wondering 'What is it like to be a wildebeest?' never loses its charm. In Animal Passions and Beastly Virtues, Marc Bekoff explores this question in the context of cognitive ethology.

The book is really a collection of papers that Bekoff published between 1977 and 2004 on five main topics. The sections on social behavior in canids and on the functions of play fit neatly into conventional behavioural ecology. The quality of these original papers varies, from an excellent and influential paper on the social ecology of coyotes to a paper on scent-marking with a single subject, Bekoff's dog Jethro.

In three sections on animal minds, interactions between humans and animals, and the ethics of studying animals, Bekoff skates boldly on to thin ice at the edges of science and philosophy. In the section on emotions, cognition and animal selves, Bekoff argues that many species have minds, emotions and a sense of self that bear recognizable similarities to those of humans. As well as providing case studies, Bekoff argues that invoking the existence of emotions or intentions often provides the most parsimonious explanation of behaviour. $\mathrm{He}$ also notes that the selection pressures that produced cognition and emotion in humans are shared by social carnivores, primates and birds, and he applies the principle of evolutionary continuity to suggest that similar outcomes may have arisen in the minds of other species. In addition to the more conventional argument that homologues of emotion are likely in non-human apes, he argues that convergent evolution may have produced emotions in species more distantly related to humans. This is thought-provolking material for anyone who wonders what the world is like for other species.

The book focuses mainly on Bekoff's work with dogs. Readers seeking broader surveys might also be interested in Animal Social Complexity edited by Frans de Waal and Peter Tyack (Harvard University Press, 2003), or Why Men Won't Ask For Directions by Richard C. Francis (Princeton University Press, 2003).

Bekoff's essays on the interactions between humans and other species raise important questions for those who study animals or who simply care about their conservation and wellbeing. The section on anthropogenic effects focuses on Bekoff's work with prairie dogs and domestic dogs. These papers are informative but for a broader view of the impact of humans on animals, the interested reader might also look at Wildlife and Recreation by R. L. Knight and K. J. Gutzwilller (Island Press, 1995).

The ethics of our interactions with other species provides the basis for some challenging discussions. Bekoff often concedes that these issues cannot be resolved, but he makes a compelling case that the questions are worth our attention. He argues that we should apply the precautionary principle to our interactions 
with animals. In conservation biology, we should err on the side of caution when forced to make recommendations based on imperfect information. He makes a thoughtful case that because we cannot be sure that animals are not conscious, emotional individuals, it is wise to treat them with dignity and tread lightly. We need to be reminded of this point.

In short, this is a thought-provoking book that forces the reader to consider issues that are important but are often left at the fringes of our work. I found a lot with which I agreed, and a lot with which I disagreed. Examples of each might be revealing.

First, two disagreements. Bekoff argues that "classical definitions cannot be given for key terms in cognitive ethology, but it is not neces- sary to give them in order to have a viable field of research". On this issue, I agree with Donald Griffin, who in his book The Question of Animal Awareness (Rockefeller University Press, 1976) took pains to state at the outset ${ }^{\alpha}$ this is what I mean by mental experiences" and went on to define 'mind', 'awareness', 'intention' and 'consciousness.' In my view, one cannot test a falsifiable hypothesis that a species has intention without first clearly defining what intention is. Bekoff also supports Stephen Jay Gould's assertion that "the plural of anecdote is data . I agree that anecdotes can offer important insights, but anecdotes are collected and disseminated selectively, whereas data are collected systematically or randomly. The plural of anecdote is not 'data,' but 'essay'.
And here are two agreements. "We will never learn about animal morality if we close the door on the possibility that it exists. It is still far too early to draw the conclusion that human morality is different in kind from animal morality and walk away in victory." And: "While ignorance may be bliss, ignoring questions about our ethical responsibilities to animals compromises not only their lives and our integrity, but also the quality of scientific research". Marc Bekoff, by forcing us to consider animal minds and our ethical obligations to animals, is pushing the field of behaviour in interesting directions.

Scott Creel is in the Department of Ecology,

Montana State University, Bozeman,

Montana 59717, USA.

\section{A ship, gradually lowering sail}

The Long History of Old Age

edited by Pat Thane

Thames \& Hudson/Oxford University Press: 2005. 320 pp. $€ 25 / \$ 49.95$

\section{Douwe Draaisma}

Even when advanced in years, Lady Sarah Cowper (1644-1720) was still a keen observer, especially of other women. After meeting with "Lady W. she confided to her diary that W. had "rent her face with painting. She is at least as old as I am and hugely infirm yet affects the follys and aires of youth, displayes her breasts and ears, adorns both with sparkling gems while her eies look dead, skin rivell'd, cheeks sunk, shaking head, trembling hands." Lady Sarah strongly felt that one should act one's age. She herself was perhaps 'elderly', but definitely not 'old'. She admitted to being old only when she was in her mid-sixties, and then it was related to diminishing eyesight and the loss of her faculties for reading and writing, rather than to her age as such.

Lady Sarah's observations are discussed in The Long History of Old Age, a delightfully written and illustrated monograph edited by Pat Thane, who has herself a long history of writing on old age. Defining 'old' in terms of infirmities and physical weakness, as Lady Sarah did, turns old age into a category with diffuse boundaries - certainly more diffuse than they are today, when in many Western countries 65 is the age of mandatory retirement. For most of the history of old age, pensions or annuities never coincided with retirement from work, and most people laboured as long as their health permitted.

The team of historians headed by Thane sets the record straight on many popular conceptions of old age. It is not true that before the twentieth century hardly anyone reached old age. Life expectancy was considerably lower, but this was due to high infant and child mortality rates. Those who reached adulthood had a good chance of living into

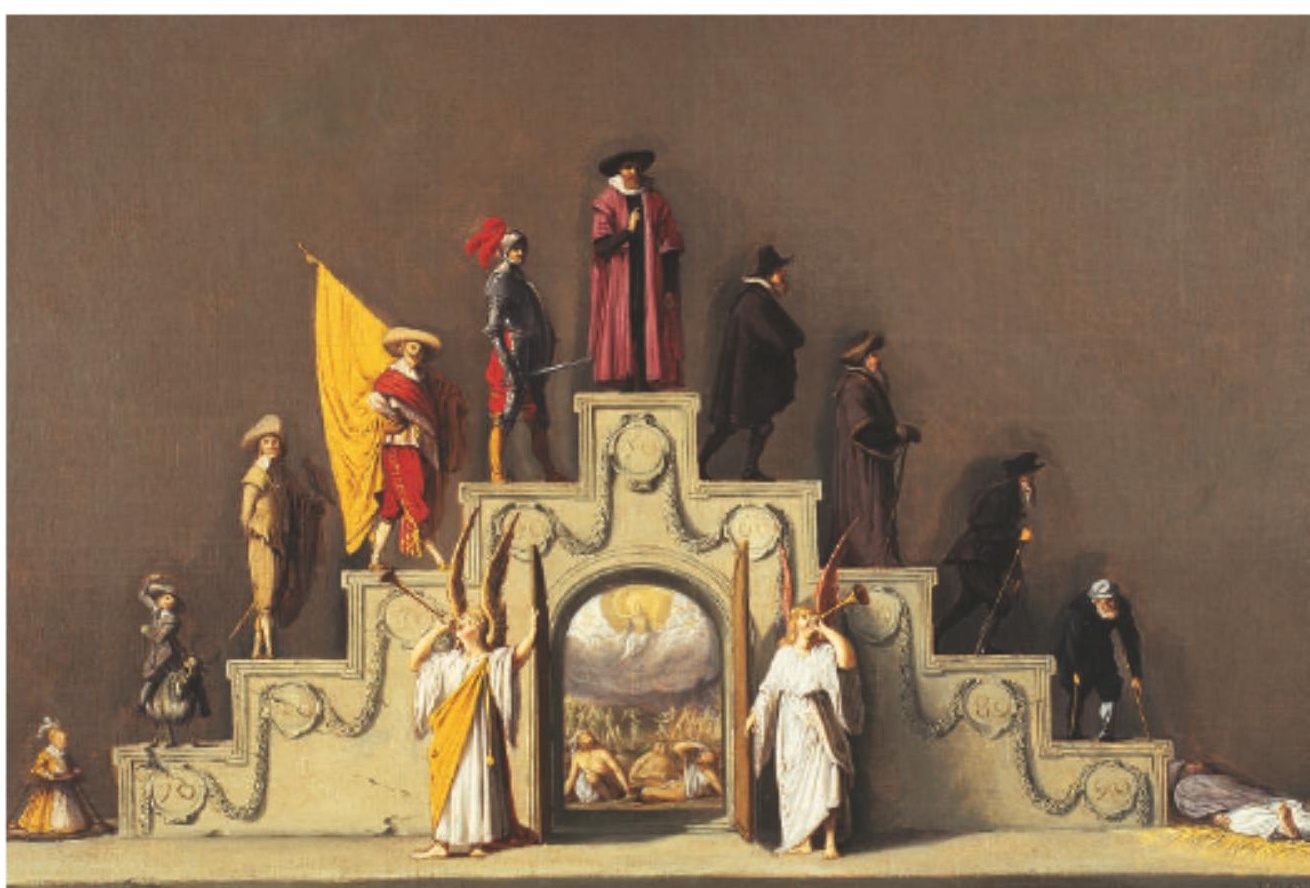

The downward path: a seventeenth-century view of a man's progression through life.

their sixties. It is equally untrue that older people are less respected today than they used to be, or that it was common for children to welcome their ageing, sickly parents into their own household.

In her introductory chapter, Thane provides evidence that the belief that the elderly were treated with more respect in the past is itself very old. As for two or three generations living together in one happy household, demographic statistics tell a grimmer tale. In the ancient Greek and Roman worlds, a ten-yearold would have only a $50 \%$ chance of having any of his grandparents alive. And if you lived to be 60 in the eighteenth century, you had only a one-in-three chance of having at least one surviving child. Given the average age of marriage and the infant mortality rate in the nineteenth century, a three-generation family was probably rarer than a four-generation family today. When parents lived with the family of their children, it was often for reasons of need and poverty. Then, as today, the elderly liked to keep their independence as long as was reasonably possible.

What this book does superbly is the wedding of demographic information, scarce as this often is, to evidence taken from the visual arts, literature, philosophy and personal documents such as letters and diaries. Some of the finest parts of the story are in the illustrations. The captions are perceptive, brief essays in themselves, that re obviously written by an (unspecified) author with an eye trained in the history of art.

Considering the span - from antiquity to 